\title{
CONTROL OF SPATIAL PROTECTION IN KAUMAN SEMARANG
}

\section{Atiek SUPRAPTI, Nurdien H. KISTANTO, Edward E. PANDELAKI, Djoko INDROSAPTONO}

\author{
Department of Architecture, Faculty of Engineering, Diponegoro University, Jl. Prof. Soedarto, \\ Tembalang, 50273, Semarang City, Indonesia \\ E-mail: atiekbudiarto@gmail.com (corresponding author)
}

Received 14 May 2017; accepted 31 October 2017

\begin{abstract}
Locality and cultural identity aspects are very important to create humane cities in the midst of globalizing world. Kauman Semarang is the city's cultural identity which has lasted for more than three centuries. Traditionally, Kauman is a village in downtown which reflects Moslem daily live. The physical and social characteristicschange are the reaction of modernization-capitalization pressure of the downtown. The purpose of the research is to find out how Kauman adapts to the incoming pressures. The research was based on ethnographic method by combining ideographic and architectural approaches. In the end of the research, it found that there is a spatial control having protective characteristic or a control of spatial protection conducted by the community. Socioreligious values have influenced in strengthening socio-religious space that produces immaterial products associated with the community's mentality. Meanwhile, the modernization-capitalization pressures influence the form of significantly developed business-commercial space, and their products are eventually used to support the socio-religious activities. Spatial protection strategy is an answer for the problem of modernization-capitalization pressures in downtown. This finding could be a useful input for the preservation efforts at Kauman Semarang particularly and for cities having similar problems generally.
\end{abstract}

Keywords: power of place, cultural heritage, sustainable development, urban village, trancendence, qualitative research.

\section{Introduction}

The influx of foreign capital as the global expansion affects the homogenizing in built environment (Samalavicius 2017), an alson in people's economics, and social structure (Santoso 2013; Zahnd 2006). The uncontrolled development of capitalistic economic space in downtown has pushed the changing of urban functions, especially the social space. It will eventually trigger a cultural lag (Ishomudin 2005), creating both a place and non-place (Tomlinson 1999). The efforts to strengthen, maintain, and develop the local identities of a city are needed to ensure the social harmonization (Hayden 1995; Arefi 1999; Serageldin 2001; Yuwono, Wardiningsih 2016).

Settlement is defined as a dwelling space having a socio-cultural relationship, transcendental aspects, and communication (Rapoport 1983; Snyder, Catanese 1979; Hayden 1995; Budihardjo 2006). Furthermore, in order to overcome 'placelessness. Arefi (1999) suggested two choices namely emphasizing the architectural landscape and developing the culture. Further physiology of space namely place attachment and place identity should be concerned in the making of the spirit of place (Hidalgo, Hernandez 2001; Scanell, Gifford 2010; Rollero, De Piccoli 2010; Devine-Wright, Clayton 2010). In the other side Lefebvre (1998) and Salama (2010) stated about the three variables in the making of the characters of place, which are social relationship, capital, and government.

Many studies about place theory focuses on the physical aspects (Cullen 1961; Morris 1979; Lynch 1981; Shirvany 1985; Koztof 1991; Zaydulfar 2002); on the socio-cultural aspects (Norberg-Scultz 1979, 1986; Trancik 1986; Hayden 1995; Hanson, Hillier 1987; Piselli 2007; Pino, Hormazabal 2016); on the social-economic aspects (Lefebvre 1998); on the trancendental aspects (Rapoport 1983; Tjahyono 1989; Prijotomo 1992; Pangarsa 2006; Ronald 2005, 2012; Purwanto 2007; Santoso 2013; Triatmojo 2010, Suprapti 2016). Generally Kauman is a settled area in "Javanese Cosmic City" around The Great Mosque built for santris and kyais and their relatives. Previous studies on Kauman villages have been done in Yogjakarta (Mulyati 1995), Surakarta (Karsono 1996; Setyaningsih 


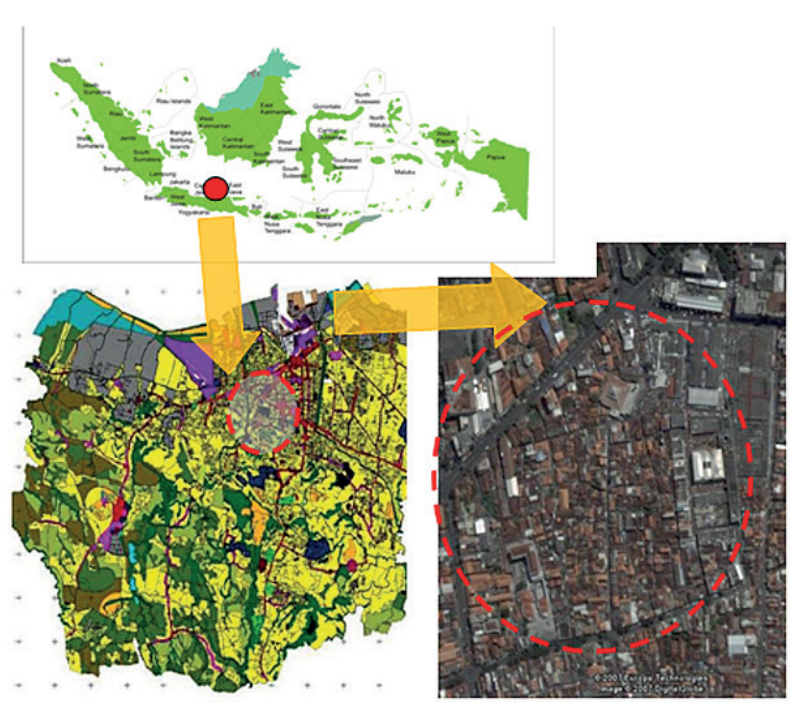

Fig. 1. The area of research: Kauman Semarang

et al. 2015), Semarang (Suprapti 1997), Jepara-PatiKudus (Marwoto 2001). These researches focus on the cities' morphology and their physical conditions. Then the research on the Kauman Kota Gede conducted by Trihatmojo (2010), and the research on Kauman Kudus done by Sardjono (2016) also focus on transcendental aspects. Kauman Semarang is a heritage village with transcendental aspect constructed by time, social cohesion, economic activities, and a strong religion (Suprapti 2016). Resisting to modernization-capitalization pressures, Kauman has been successful showed its resilience as a Moslem urban village. It is needed an inquiry to figure out how Kauman has the power of place, which has made it sustainable. The research purpose is to find out the unique socio-cultural-religious-economic spatial consepts at Kauman village.

According to the Act No 11/2010 of the Republic of Indonesia, Kauman is classified as a cultural heritage area, but the laws that aims to preserve still have a weakness particulary related to the techniques snd mechanisms of implementation.

\section{Methods}

\section{Research Strategy}

Grand tour: Grand tour is also called descriptive observation. An observation over the entire study area is conducted in order to have initial description of the space (Fig. 1) where main activities and space are located.

Mini Tour: On this stage, the observation was done in two chosen observed units: (a) Kampong Pompa and (b) The area around the Great Mosque. Then, researchers searched for the spatial domain. It is a spatial meaning which contains sub-domains, and inside these sub-spatial domains contain some symbolic terms (Spradley 1997).

\section{Domain Analysis}

After finding the first domain, we analyzed it to find out the next domains and to test whether it supports the hypothesis or weakens the domain. Then, the following domains were found and they were: (1) the worship place, (2) the dwelling space, (3) the kinship space, a place of educating character and (4) the workplace.

\section{Focused Analysis}

After deciding the observation focus, researcher conducted a focused observation by analyzing symbols guided by questions originated from the relationship between sub-domain and spatial language elements.

\section{Taxonomic Analysis}

Directing the internal structure of each domain aimed to figure out the ordering principles of the original spatial domain symbols.

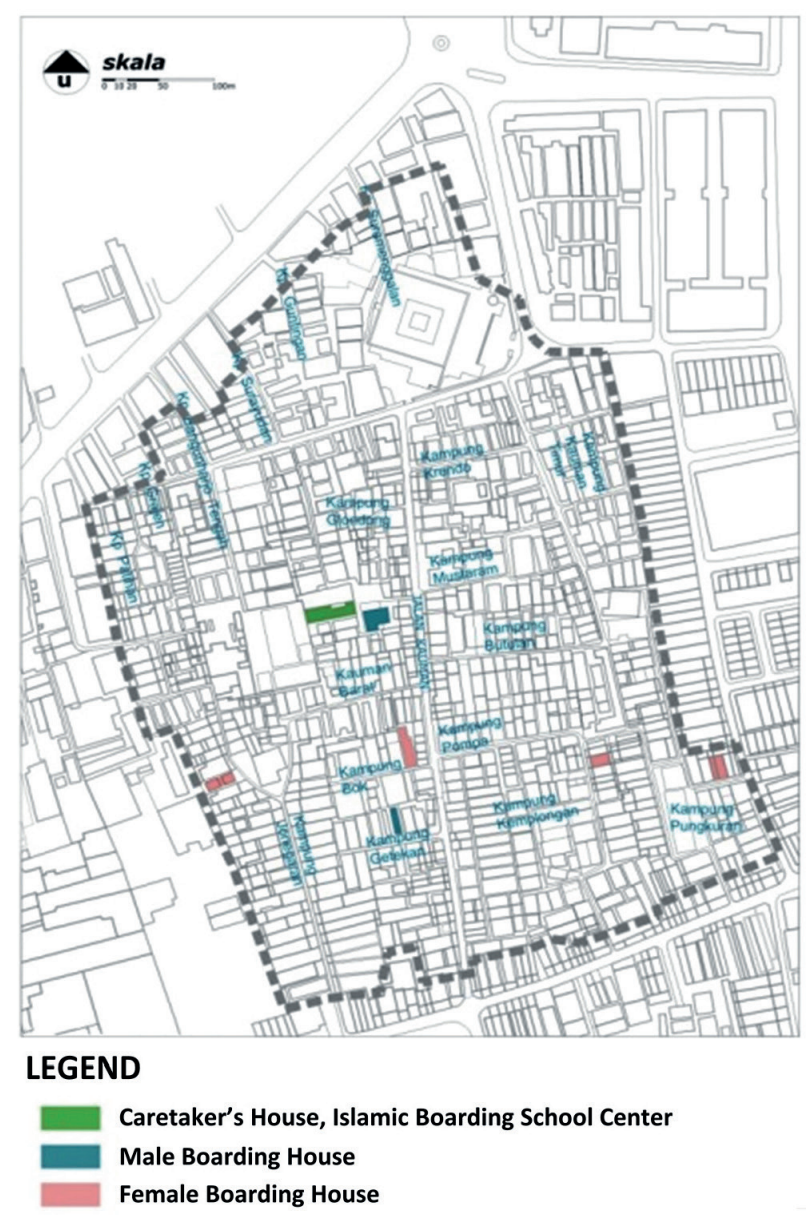

Fig. 2. The Distribution Map of the Buildings Endowed by Citizens for Raudhatul Qur'an Islamic Boarding School in 2015 
Componential Analysis

Componential analysis was conducted to understand the meaning better through observation on how symbols were connected one another. Researcher narrated the symbols obtained on the field. To find the meaning, researchers asked several questions to the informants. Formulation of Empirical Themes.

A theme is a cognitive principle recurred either openly or closely in several domains and functions as the relationship among the meaning branch systems. The themes found were recorded then, and they were grouped into categories based on the relationship occurred among them.

After conducting comprehensive observation on the mini tour in the Kampong Pompa, researcher found 18 eighteen empirical themes. These themes were from the searching of meaning based on data taken from the field (see Table 1). After that, the analysis of spatial symbols by finding out relationship among them within four domains at Kauman - was conducted. On four existing domains, empirical themes appeared repeatedly. Those findings were grouped into several categories then.

Table 1. Recording of empirical themes

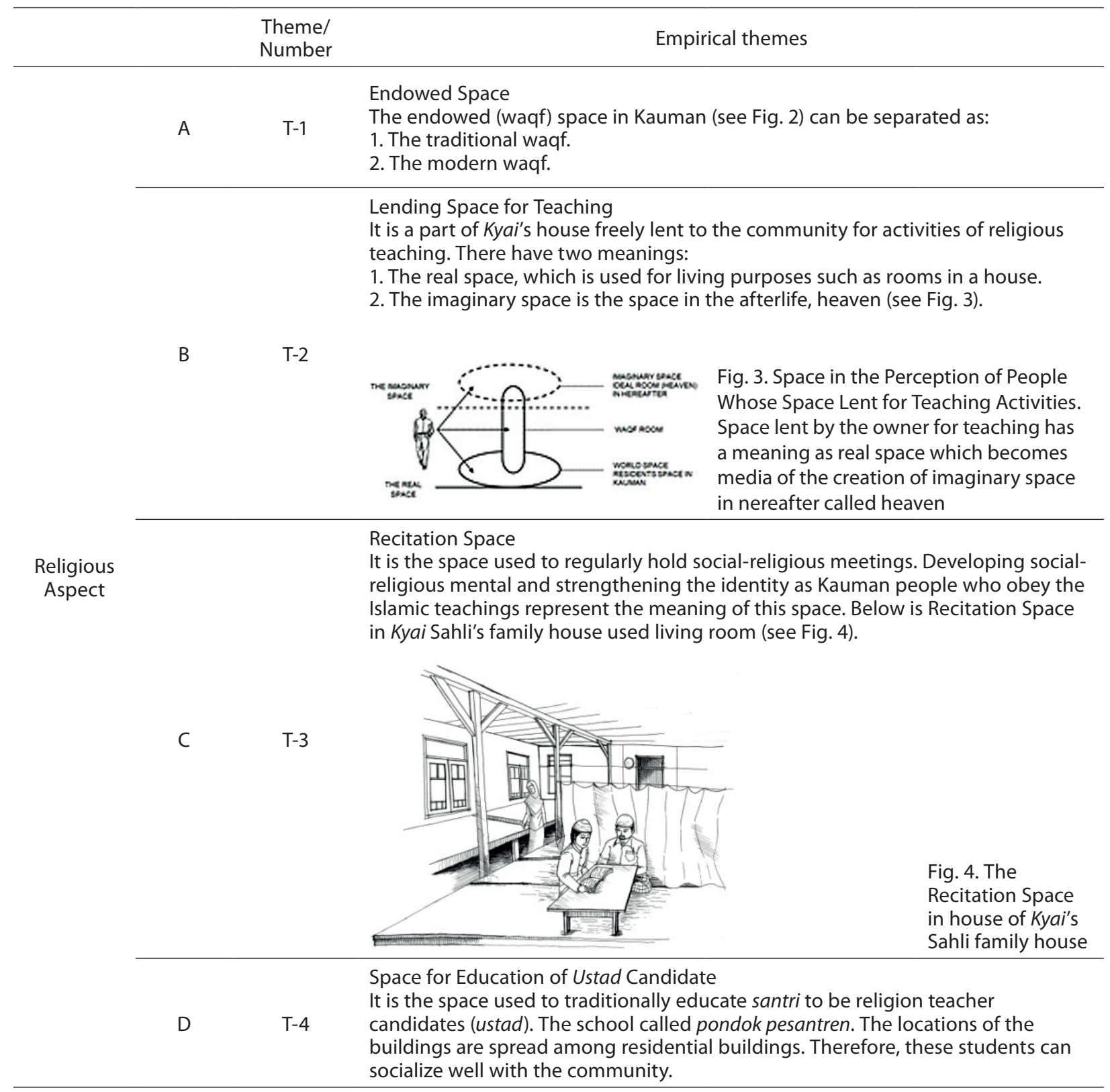


Continued of Table 1

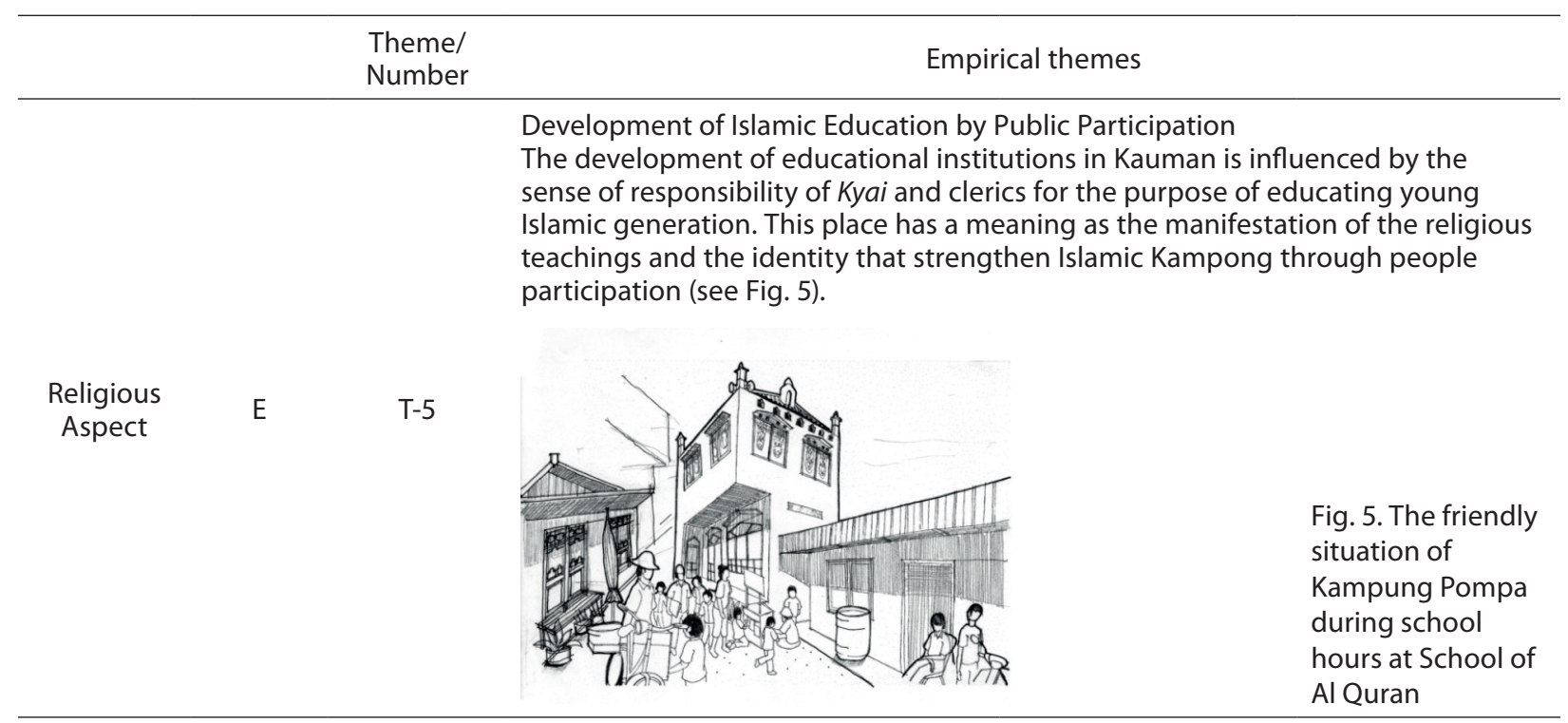

\section{Businessmen Dominate the Building Ownership}

This theme was firstly triggered by the development of Kauman businessmen,

A T-6 then by the desire to stay at Kauman, and finally by the idealism of protecting this place from the incoming non-locals. This theme means the transfer of buildings' ownership from the first owners to the local businessmen.

Celebrations for Self Existence

The space for feasts as self-existence is the space to express the identity of

B T-7 Kauman people by performing celebrations as a sign of accomplishment. Three meanings: as a gratitude for God, as a religious preaching, and as a self-existence expression.

\section{Space for Kinship Ties}

C T-8 The space for kinship means the space for building close relationship among members of the family and the space for continuing positive activities previously done by the ancestors for the benefit of Moslem community.

Representation of the Architecture Dynamics in Semarang

The architecture of residential buildings varies from ages. It means that Kauman is a representation of architectural dynamics of residential houses in Semarang. The buildings typology can be categorized into (see Fig. 6): Javanese vernacular buildings (joglo, serotong, and limasan).

Socio-

Cultural Aspect
D

T-9

Buildings with colonial styles: indische style, art deco style. Jengki style buildings, typical of genuine Indonesian style.
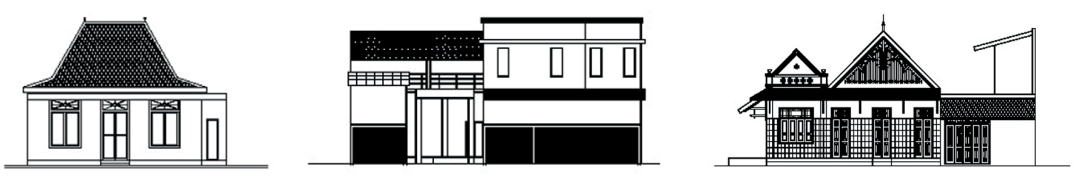

Fig. 6. From the left to the right; Joglo, Art Dec, and Indische

Unification of Domestic and Public Functions

From the result of the study, it can be concluded that the economic functions F T-10 tend to be at the accessible zone. The unification of functions may occur between spaces.

Easy Controled Space

For Kauman people, a good place for living should be close to the mosques, the work places, and the relatives.

Controlled Street Network

The function of the streets in Kauman includes: 1) The facility for population

H T-12 movement, 2) The connector of building functions, 3) The buildings organizer in and distribute people mobility, and on the other side serve as functional spaces accomodating external social activities. 


\begin{tabular}{|c|c|c|c|}
\hline & & $\begin{array}{l}\text { Theme/ } \\
\text { Number }\end{array}$ & Empirical themes \\
\hline \multirow{6}{*}{$\begin{array}{l}\text { Socio- } \\
\text { Cultural } \\
\text { Aspect }\end{array}$} & I & $\mathrm{T}-13$ & $\begin{array}{l}\text { Space of Protection for Women } \\
\text { There are the spaces used for public activities that give special place for women. } \\
\text { Instead of undermining their roles, these spaces are for protecting women, so } \\
\text { they can do their activities optimally. }\end{array}$ \\
\hline & $J$ & $\mathrm{~T}-14$ & $\begin{array}{l}\text { Space for Tolerance } \\
\text { The space for tolerance occurs due to the presence of an interested party using } \\
\text { the public space, to carry out a private activities (economic activities or socio- } \\
\text { religious activities) held in public spaces such as on alleys or streets. The attitude } \\
\text { of the people around in responding to these events is to respect the use of these } \\
\text { spaces. It happens because the local community prefers to live in harmony and in } \\
\text { friendly atmosphere. }\end{array}$ \\
\hline & $\mathrm{K}$ & $\mathrm{T}-15$ & $\begin{array}{l}\text { Borrowed Spaces } \\
\text { Borrowing space is a solution to resolve spatial conflicts due to mass activities } \\
\text { dealing with limited quantity of space in case there is an agreement between the } \\
\text { owner of the activity to expand the space by borrowing the private space of the } \\
\text { surrounding neighbors. }\end{array}$ \\
\hline & $\mathrm{L}$ & $\mathrm{T}-16$ & $\begin{array}{l}\text { Commissioned Space } \\
\text { The commissioned space is relate to the endowed (waqf) space, which is occurs } \\
\text { when wakif (the person giving endowment) trusts a stuff/property to nadhir (the } \\
\text { agency that manages waqf) to be used for religious activities. The trusted space } \\
\text { is in the waqf space because the nadhir has a commitment to share it to other } \\
\text { institutions for religious purposes The management is still in the hands of nadhir, } \\
\text { but the party who gets the space can utilize it freely based on the socio-religious } \\
\text { consideration. }\end{array}$ \\
\hline & A & $\mathrm{T}-17$ & $\begin{array}{l}\text { Moslem Trading Corridor } \\
\text { Trade corridors are characterized by Moslem praying stuffs. The space is the knot } \\
\text { between the worldly activities that drive the worldly economic energy (terrestrial } \\
\text { energy) with religious activities that connects to the spiritually divine energy } \\
\text { (celestial). }\end{array}$ \\
\hline & C & $\mathrm{T}-18$ & $\begin{array}{l}\text { Village of Traders } \\
\text { This theme is regarding to the areas within the village are used by traders/ } \\
\text { entrepreneurs to stay. These areas function as places to live and to do business as } \\
\text { their characteristic. The traders/entrepreneurs like to live in this area because of } \\
\text { its proximity to their business place, so they can control the activities both in their } \\
\text { home and in their business place. }\end{array}$ \\
\hline
\end{tabular}

\section{Construction of the Theory}

\section{Formulation of the Empirical Concept \& Theory}

An empirical concept is a group of themes resulted from an empirical research consisting of certain concepts. This stage is conducted by grouping themes into particular empirical concepts. The grouping is conducted after analyzing the relationship between themes and categories.

After the themes were grouped into some concepts, the theoretical concept was formulated. Therefore, we needed to analyze the empirical concepts based on the principle of the paradigm model. The model follows the order: (1) causal conditions, (2) phenomena, (3) contexts, (4) influencing condition, (5) action/interaction strategies, and (6) consequences.

Therefore, in this research there were nine empirical concepts, and four abstract categories one of them was chosen to be the main category. The requirements for being the main category are: (1) able to describe the empirical concepts, (2) able to respond current issues, and (3) in line with research state of the art.

\section{Data Validity Examination Techniques}

In examining data validity, the following techniques were used:

1. The extension of participation.

2. Observation persistence / constancy to strengthen data interpretation.

3. Triangulation.

\section{Results and discussion}

This inductive research found 18 (eighteen) empirical themes, and compose 9 (nine) concepts as described below:

1. Space for Obtaining Blessings (SOB) consists of: (a) Endowed Space (b) Lending Space for Teaching and (c) Agreement Space for Religious 
Activities. The concept of SOB is a space constructed to implement the teaching of the religion in order to obtain blessings from God.

2. Spiritual and Islamic Education Space (SIES) involves: (a) Recitation Space, (b) Space for Educating Ustad Candidates, (c) Development of Islamic Education by Public Participation. All of them are space which always drives the spirit of honored manners of a Moslem.

3. Islamic Syiar Space (ISS) is a space functioned to facilitate organizations spreading Islam. It is composed of several themes: (a) Simple Islamic Syiar Space, (b) Islamic Education Networks. Here the place attachment is according to the similar motivation based on religious guidance.

4. Self-Protection Concept (SP) is a spatial concept for celebrating the cultural tradition/monumental events of an institution. It is needed to show the existence of institutions in Kauman. This theme is composed of: (a) Businessmen Dominating the Buildings Ownership and (b) Celebration for Self Existence.

5. Dignity Concept (D) is an attempt to carry on/conserve the family inheritance or tradition by utilizing kinship space. It is composed of the themes like: (a) Space for Kinship Ties and (b) Continuing the Familial Inheritance Related to Religious Education.

6. Historical Heritage (H2), is a spatial concept associated with the preservation of historical heritage of architecture in Kauman. It has a theme entitled: Representation of Architecture Dynamic in Semarang.

7. Control Space (CS) is a spatial concept constructed in order to obtain an effective and optimum space control and to facilitate socio-religious and economical activities in a limited space. It is composed of: (a) Unification of Domestic and Public Functions, (b) EasilyControllable Space, (c) Controlled Street Network, (d) Space of Protection for Women.

8. Symbiosis Space (SS), is a concept occurred because of the interaction among spaces. The differences among them are the benefits and the kinds of activity. It is composed of: (a) Space for Tolerance, (b) Borrowed Space, and (c) Commisioned Space.

9. Trading Space (TS), is a concept used for trade/business activities which plays a vital role in economic and socio-religious life. It is composed of: (a) Moslem Trading Corridor, (b) Traders Village.
This research found four categories from the inductive process, there are: (1) Jihad ${ }^{1}$ Space, (2) Moslem Trading Space, (3) a Control of Spatial Protection, and (4) Symbiosis Space. One of them is the candidate of "main category" based on the process of theory construction.

Therefore, Kauman community, either the main class or the traders, agreed to control Kauman's development by protecting space from inside to prevent: (1) The incoming outsiders considered to have different ideology and belief, and (2) the influx of investment from outside. On the other hand, "A Control of Spatial Protection" (CSP) is the plot main problem. It can be described as follows. CSP closely related to the motivation of Kauman community to actively contribute in socio-religious and economic life. The concept which is aimed to conserve the existence of “ Kauman's local characters" or "as Kauman People" facing public modern capitalistic pressures. Therefore, researcher focused on "CSP" since this phenomenon always exists and clearly emerges whenever observations and interviews with the informants were conducted. The Theory Construction: A Control of Spatial Protection. This research found nine concepts of space both of them are other prominent categories like: consept-5 Dignity Space (D), and concept-6 Historic Heritage (H2). Both of categories construct the main concept a Control of Spacial Protection It is the nature that provides control to protect themselves from outside influences that tend to be destructive.

Kyai Khanief Ismail said that: “....one of Kauman people's duties is to foster the religious morality of their young generation, so they will have a strong Islamic character and be able to control the social change... entrepreneurs and scholars in Kauman synergize together to withstand the influx of visitors especially those having different beliefs'. This fact merely protects the integrity of Kauman from negative influences from outside".

Then, it can be concluded that "Space for Obtaining Blessings" consists of: a) Endowed Space, and b) Lending Space for Teaching. Both concepts above are considered as the creators of spatial jihad. Spiritual of Islamic Education Space forming: a) Recitation Space, b) Space for Educating Ustad Candidates, and c) Development of Islamic by Public Participation. during a jihad of space actively working, it will have the opportunity for space conflicts, between space for economic and space for social activities. Islamic teachings encourage a Moslem

1 The generally definition of jihad is invocation of ad-dakwah calling on the amar makruf nahi munkar, and conquest of lust, the war. The form of jihad in Islam's doctrine: jihad dakwah, jihad through thought and knowledge, jihad with weapons, and jihad in the way of God with sacrifice of wealth and soul. 
to wage jihad with his wealth in the path of God for the cause of Islam (Almascaty 2001). Regarding the concept, Kyai Khanief Ismail said: "Islamic Kauman is a jihad in the way of Allah, in the center of the city facing the pressure of capitalization-modernization".

Confronted with the pressure of modernizationcapitalization, on its social space, the Kauman people engage in "control of spatial protection", which is a control that tends to protect the place. Further they create "self-protection" which is an actions aimed at self-protection against the external pressure included: a) Businessmen dominate the building ownership and b) Selebration for Self Protection. This strategy was created by the social phenomenon called "Spatial Jihad". Spatial jihad consists of: a) Space for Obtaining, and b) Endowed space. If the Endowed Space increases, Then Kauman will be strongger with its protective character.

As Kyai Khanief Ismail stated:“..... Our job is to prepare and provide a good moral to the community and control to the younger generation's morality. This provision includes secular sciences and the Holy Quran wisdom taught by School of Quran reading that develops because of the support of waqf from the citizens".

Furthermore, the perception of residents on built environment have a meaning from global up to affective (Hillier, Peponis 1997). According to the statement, The more modern the characteristic of endowed space, the more global Kauman people's perception even though it will weaken the protective character. This will be related to the weaken of place identity (Morgan 2010; Devine-Wright, Clayton 2010). In addition, it will decrease the tendency of and Islamic Education Space consisting of independent variables: Recitation Space, Space for Educating Ustad Candidates and dependent variable: Space of Islamic Education Development. When the independent variables are stronger, the dependent ones will be stronger Lending Space for Teaching in which it has been traditionally decreased, and eventually Kauman will be more global. As the consequence, When will be more global, its protective character will be weakened. However, it is influenced by the condition of "Islamic Trading Space" composed of independent variables: (a) Moslem Trading Corridor', and dependent variabel (b) Village of Traders. If Moslem Trading Corridor is strengthened, Village of Traders will strengthen either. This situation will give impact for strengthening of the CSP, but the socio-cultural characters will weaken, there will be more business-oriented, and will increase the internal capitalism. As the consequences of CSP on spatial setting is the existence of: (a) Space Control (SC), and (b) Symbiosis Space (SS) (see Fig. 7) Wibawa (2014) explaining that social interaction within social groups will affect social identity and structure.

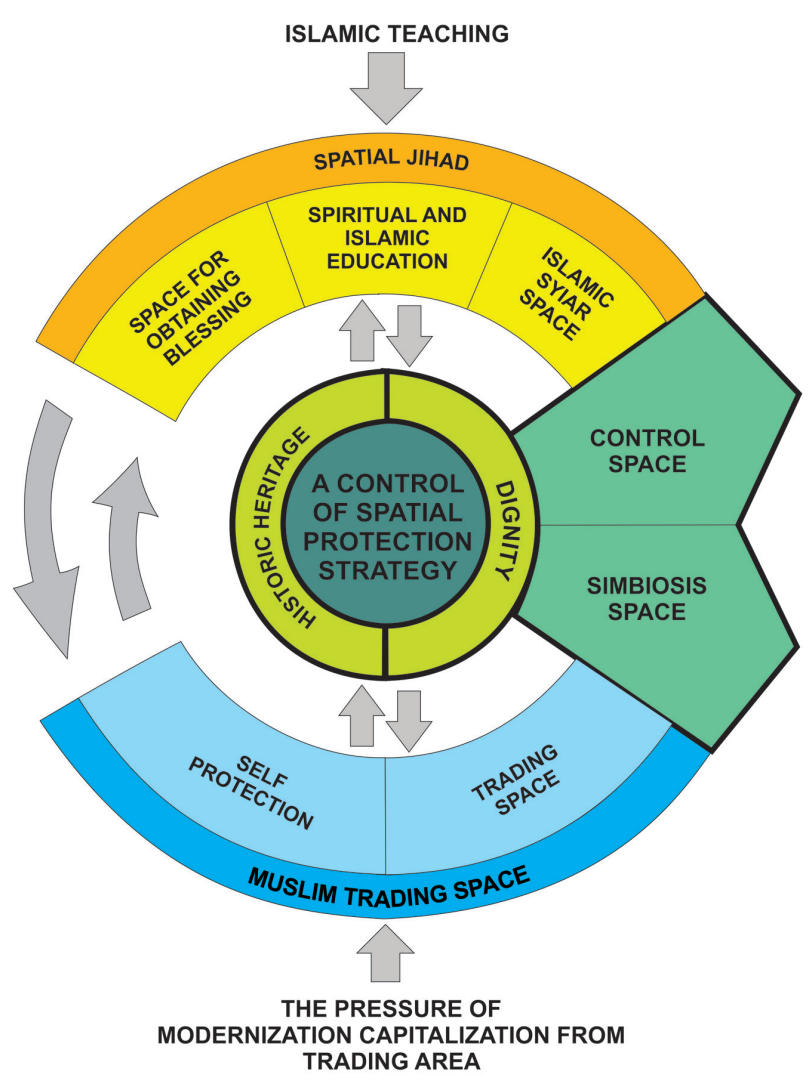

Fig. 7. The Diagram Of "A Control of Spatial Protection" Building Theory. "The Control of Spatial Protection" Theory Kampong Kauman Semarang concepts which was found include: (1) space for obtaining blessings, (2) spiritual and islamic education space, (3) symbiosis space, (4) control space (5) trading space, (6) Islamic Syiar space, and (7) self-protection space. Besides, there are other prominent categories like: (8) dignity space, and (9) historic space which are the characters of the main concept, the protective control

\section{The control of spatial protection as a power of place in dealing with the modern-capitalistic pressure}

The Kauman spatial protective control strategy will work when there are signs such as: the trading space, Moslem trading corridor and these signs grow stronger. This fact will make the traders who come from the cleric's family feel that, they need to keep the balance of the life and the afterlife. Therefore, they should implement the by spreading Islam through "Spatial Jihad". At the condition where the spatial subjects are motivated by "Spatial Jihad". They contribute the space to gain blessing, because they learn life experiences from their parents and their habitat. This thing is associated with affection and love living from time to time which is known as a place attachment (Scannell, Gifford 2010). They actively involve in building the good moral according the Islamic teaching activities then formalize it into the religious organizations, according to the theme of Spiritual and Islamic 
Education Space. This Moslem habitat character in Kauman has attached as place identity. Particulary in pondok pesantren the place identity is dominant. This fact is in contrast to the research result of Qingjiu, and Maliki (2013), who found that the place identity in a campus is quite weak. Pondok pesantren in Kauman is a traditional education institution, the manager try to make the dormitory mixed with surrounding environment, so that santris can mingle with their habitat. In order to exist as "Kauman Society", when their place to live are massively pressured by the commercialization, the community use the CSP strategy which consists of self-protection action and reinforcing the dignity action. The Self Protection as well as the Dignity action are caused by kinship, religious motivation as well as shared identity as Kauman people which are known as the place identity (Blackshaw 2010). The strong bond of shared identity as the descendants of some kyai has created the place identity (Blackshaw 2010) and the place attachment (Scannell, Gifford 2010). As the consequence, the people implement the spatial control and symbiotic endowment based on the socio-cultural values and manage the public space by prioritizing mutually beneficial cooperation, in order to run the mandate activity in accordance to the teaching of Islam, The management of conflict in this place is very good because it prioritizes harmony in accordance with religious teachings (Hoban, see in Ikaputra 2014). If the symbiotic endowment is implemented successfully, then the Kauman people will be able to overcome the modern-capitalistic pressures towards their living space and also strengthen their existence as Kauman residents. Character of this kampong has been reviving the city centre (Setiawan 2010).

The space in Kauman is constructed through the social bond and the periods of time because the space exists from the communities' comprehension who feel responsible for the Syiar Islam. Kauman's physical space is formulated from close social-cultural, religious relationships (Eranil Demirli et al. 2015; Piselli 2007; Hanson, Hillier 1987; Pino, Hormazabal 2016). Lefebvre (1998), and Rioux et al. (2017) defined this as "appropriated space". This space is described as space that is used to implement the purpose of spreading Islam based on the monotheism and the kinship systems that demand them to continue the tradition of teaching religion. Referring to those theories, Kauman tends to be close to both of the need and the desire concept. The resources are close to the character of compact city (Rochyansyah 2008), which has: first, mixed uses: educational buildings and structures, recitation spaces, residences, buildings for bussiness, and buildings for worship; second, the mingling any building with all ages and types; third, sufficient density; and workable scale environment. In the other side, Kauman conserves the immaterial forms such as: science, culture, faith in religion, kinship connections. This energy is needed by Kauman to achieve its mission which is spreading Islam. This is the character of compact city, complete with the strong of sense of place.

Thus Kauman has strong the sense of place that contains the place attachment and the place identity (Tuan 2008; Scannell, Gifford 2010; Qingjiu, Maliki 2013; Devine-Wright, Clayton 2010) that have equal power, hence making Kauman people feel comfortable and stay. The place attachment and the place identity cannot be separated.

We can put the label "the conspiration of space" by Triatmojo (2010) is also founded in Kauman Semarang, it can be labeled as "the Commission Space" t because it has been dominated by the interaction process between two spaces or more which have been based on religious teaching. The modern-capitalistic pressure has changed the way of life of the Kauman residents in Semarang. That is why the Kauman Semarang residents work very hard as traders or entrepreneurs, so they can get the infrastructure benefits to enjoy worldly happiness, and in the same time, they thrive to do good deeds as their provisions in the hereafter. This effort is called "A Control of Spatial Protection" theory, which are composed from historical-cultural landscapes (tangible and intangible aspect) and physical space. (Hayden 1995). It is also known as place identity (Devine-Wright, Clayton 2010), that is a self-description or a self-conceptualizing relating to personal and group roles.

\section{Conclusions}

For the Kauman community, space has several meanings as: (1) the media to maximally spread the religion, (2) the integration of economical, socio-cultural-religious aspects, and (3) the knot tying two energies of terrestrial and celestialand keeping them balanced.

The local theory of "A Control of Spatial Protection" is the part of "Place" theory that is mostly discussed in the field of urban architecture. The research characteristic is susceptible to influencing factors because it has social aspects that easily change. "A Control of Spatial Protection" is a substantive theory that answers the problem related to the competition between political-economic interests and socio-cultural interests for space. The proposition on the substantive theory of "A Control of Spatial Protection" in Kauman Village is as follows, "if there is a causal condition of spatial jihad, and condition affecting Muslim trading space, it will create a control of spatial protection strategy, which will encourage a consequence in the form of space arrangement 
to embody a control space and a symbiosis space". The next development of Kauman should pay attention to the local concepts that have been found in this research.

The government needs to issue a provincial act related to the establishment of Kauman as the conservation area and as the local heritage of Semarang City, so the illegal occupation of the lands or buildings and other environmental problems can be avoided. In addition, a uidance on planning and designing an area that focuses on the research results needs to be made to protect and safely develop all potency at Kauman.

\section{Acknowledgements}

Great thanks would be to: Dr Kim Saehoon from GSES Seoul National University; Prof. Imam Buchori, Mr. Anang Wahyu Sejati, Prof. Sugiono Soetomo, the late Prof. Eko Budihardjo, from University of Diponegoro; and the late Dr. Galih Widjil Pangarsa, from Brawijaya University - for the ideas, thoughts, suggestions in completing this article.

\section{References}

Almascaty, B. J. 2001. Panduan Jihad untuk Aktifitas Gerakan Islam. Jakarta: Gema Insani Press.

Arefi, M. 1999. Non-place and placelessness as narratives of loss: rethinking the nations of place, Journal of Urban Design 4(2): 179-193. https://doi.org/10.1080/13574809908724445

Blackshaw, T. 2010. Key concepts in community studies. London: Sage. https://doi.org/10.4135/9781446279076

Budihardjo, E. 2006. Sejumlah Masalah Permukiman Kota. Bandung: P. T. Alumni.

Cullen, G. 1961. The concise townscape. London: The Architectural Press.

Devine-Wright, P.; Clayton, S. 2010. Identity, place, and enviromental behavior, Journal of Environmental Psychology 30: 267-338.

https://doi.org/10.1016/S0272-4944(10)00078-2

Eranil Demirli, M.; Tuna Ultav, Z.; Demirtaş-Milz, N. 2015. A socio-spatial analysis of urban transformation at a neighborhood scale: the case of the relocation of Kadifekale inhabitants to TOKİ Uzundere in İzmir, Cities 48: 140-159. https://doi.org/10.1016/j.cities.2015.06.013

Hanson, J.; Hillier, B. 1987. The architecture of community: some new proposals on the social consequences of architectural and planning decisions, Architectural and Behavior 3(3): 251-273

Hayden, D. 1995. The power of place. London: Thames Hudson Ltd.

Hidalgo, M. C.; Hernández, B. 2001. Place attachment: conceptual and empirical questions, Journal of Environmental Psychology 21: 273-281. https://doi.org/10.1006/jevp.2001.0221

Hillier, B. H.; Peponis, J. 1997. Syntactic analysis of Settlement, Architecture and Behavior 3(3): 217-232.

Ikaputra. 2004. Toward open and acessible public places, in Proceeding International Seminar on Managing Conflic in Public Places Through Urban Design, Magister Design Kawasan dan Binaan UGM, Yogjakarta.
Ishomuddin. 2005. Sosiologi Perspektif Islam. Malang: Universitas Muhamadiyah Malang.

Karsono, D. 1996. Kajian Perubahan Bentuk Tata Ruang Lingkungan Permukiman di Kauman Surakarta: Master thesis. Program Pascasarjana Universitas Diponegoro, Semarang.

Koztof, S. 1991. The city shaped. London: Thames Hudson Ltd.

Lefebvre, H. 1998. The production of space. Blackwell Oxford UK \& Cambridge USA.

Lynch, K. 1981. Good city form. USA: MIT Press.

Marwoto. 2001. Kampung Kauman di Pesisir Utara Jawa Tengah Kasus Studi: Kauman Jepara, Kauman Kudus Wetan dan Kauman Pati: Mater thesis. Bandung: Program Magister Arsitektur, Institut Teknologi.

Morgan, P. 2010. Toward a developmental theory of place attachment, Journal of Environmental Psychology 30: 11-22. https://doi.org/10.1016/j.jenvp.2009.07.001

Morris, AEJ. 1979. History of urban form. London: George Goldwin Limited.

Mulyati, A. 1995. Pola Kampung Kauman Yogyakarta: Thesis. Universitas Gajahmada Yogyakarta, Yogyakarta.

Norberg-Schultz, C. 1979. Genius loci toward a phenomenology of architecture. New York: Rizzoli.

Norberg-Schultz, C. 1986. Architecture: meaning and place "selected essays". New Yoek: Rizzoli.

Pangarsa, W. G. 2006. Merah Putih Arsitektur Nusantara. Yogyakarta: Andi Offset.

Pino, A.; Hormazabal, N. 2016. Informal settlements: reinterpreting rural imaginary in urban areas; the case of Valparaiso ravines, Habitat International 53: 534-545. https://doi.org/10.1016/j.habitatint.2015.12.014

Piselli, F. 2007. Communities, places and social network, Journal American Behavioral Scientist 50(7). https://doi.org/10.1177/0002764206298312

Prijotomo, J. 1992. Ideas and forms of Javanese architecture. Yogyakarta: Gajah Mada University Press.

Purwanto, E. 2007. Rukun Kota (Ruang Perkotaan Berbasis Budaya Guyub) Poros Tugu Pal Putih Sampai Dengan AlunAlun Utara Yogyakarta. Yogyakarta: Sekolah Pascasarjana Universitas Gadjah Mada.

Qingjiu, S.; Maliki, Z. N. 2013. Place attachment and place identity: undergraduate students place bonding on campus, Procedia Social Behavioral Science 91: 632-639. https://doi.org/10.1016/j.sbspro.2013.08.463

Rapoport, A. 1983. The meaning of the built environment a nonverbal communication approach. Beverly Hills California: Sage Publictions.

Rioux, L.; Scrima, F.; Werner, C. M. 2017. Space appropriation and place attachment: University students create places, Journal of Environmental Psychology 50: 60-68. https://doi.org/10.1016/j.jenvp.2017.02.003

Rochyansyah, M. S. 2008. Compact city development model in Indonesia: a Kampung Oriented Development, in Proceeding of International Seminar on Green Architecture and Environment: Toward Green Compact Cities, 14 October 2008, Makasar, Hassanudidin University.

Rollero, C.; De Piccoli, N. 2010. Place attachment, identification and environment perception: an empirical study, Journal of Environmental Psychology 30: 198-205. https://doi.org/10.1016/j.jenvp.2009.12.003 
Ronald, A. 2005. Nilai-nilai Arsitektur Rumah Tradisional Jawa. Yogjakarta: Gajah Mada University Press.

Ronald, A. 2012. Pengembangan Arsitektur Rumah Jawa. Yogjakarta: Cahaya Atma Pustaka.

Salama, H. Hussam. 2010. Place production in the era og globalization the vectors of intentionality model, ACSA $96^{\text {th }}$ Annual Meeting, 27-30 March 2008, Houston, TX. Association of Collegiate Schools of Architecture.

Samalavicius, A. 2017. Rethinking modernism and the built environment. Cambridge: Cambridge Scholars Publishing.

Santoso, J. 2013. Understanding urban transformation in Asia: Case Study of Jakarta, Journal of Tata Loka 15(2).

Sardjono, A. B. 2016. Makna Tradisi Gusjigang Pada Rumah Kaum Santri Pedagang di Kota Lama Kudus. Semarang: Disertasi. Universitas Diponegoro.

Scannell, L.; Gifford, R. 2010. Defining place attachment: a tripartite organizing framework, Journal of Environmental Psychology 30(1): 1-10. https://doi.org/10.1016/j.jenvp.2009.09.006

Serageldin, B. 2001. The sacred city. New York: Routledge.

Setiawan, B. 2010. Kampung Kota dan Kota Kampung: Tantangan Perencanaan Kota di Indonesia. Yogjakarta, Universitas Gadjah Mada.

Setyaningsih, Wiwik, dkk. 2015. Proses Perubahan Arsitektural Kawasan Bersejarah Kampung Wisata Kauman Surakarta, Jurnal UNS 6(2): 69-74.

Shirvani, H. 1985. The urban design process. New York: Van Nostrand Reinhold Company.

Snyder, C. J.; Catanese, A. J. 1979. Introduction to architecture. New York: Mc Graw-Hill.

Spradley, P. J. 1997. Mengamati Sambil Ikut Serta Metoda Observasi Partisipatif. Yogyakarta: Pusat Pastoral.

Suprapti, A. 1997. Kajian Pola Spasial Kampung Kauman Semarang Sebagai suatu 'Place': Tesis Magister Teknik Arsitektur UNDIP, Semarang.

Suprapti, A. 2016. Concept of self-conservation in a traditional village an empirical study of Kampong Kauman Semarang Indonesia, International Transaction Journal of Engineering, Management, \& Applied Sciences \& Technologies 7(1): 21-34.

Tjahyono, G. 1989. Cosmos, center and duality in Javanese architectural tradition: the symbolic dimensions oh house shapes in Kota Gede and surroundings: Doctor's dissertations. University of California.

Tomlinson, J. 1999. Globalization and culture. Chicago: The University of Chicago Press.

Trancik, R. 1986. Finding the lost space: theories of urban design. New York: Van Norstrand Reinholld Company.

Triatmojo, S. 2010. Pemupakatan dan Desakralisasi Ruang Di Permukiman Kauman: Disertasi. Universitas Gajahmada Yogyakarta,Yogyakarta.

Tuan, Yi-Fu. 2008. Space and place: the perspective of experience. London: University of Minnesota Press.
Wibawa, D. N. G. 2014. Perancangan Permukiman Kota dan Kontrol Sosio Spasial. Penerbit Universitas Trisakti, Jakarta.

Yuwono, S.; Wardiningsih, S. 2016. Mempertahankan Keberadaan Kampung di Tengah-Tengah Kawasan Modern Jakarta, Jurnal Nalars 15(1).

Zahnd, M. 2006. Urban design-model for dense, laminar-based new quarters for Indonesian Cites, Inta Conference Proceeding, Duta Wacana Cristian Univesity, Yogyakarta.

Zaidulfar, A. E. 2002. Morfologi Kota Padang: Disertasi. Universitas Gajah Mada, Yogyakarta.

\section{ATIEK SUPRAPTI}

Shee is a lecturer at Department of Architecture Engineering Faculty Diponegoro University. She studied architecture and received her $\mathrm{PhD}$ in University of Diponegoro. Her research interests in urban heritage, preservation, social space. Her International experiences in several research collaborations, received many research grant, academic exchange, and international conferences. She serves as a member of various associations. Nowadays she has been serving as the head of program of doctor in Architecture and Urbanism Diponegoro University.

\section{NURDIEN H. KISTANTO}

$\mathrm{He}$ is awarded $\mathrm{PhD}$ from Faculty of Letters, Diponegoro University He holds a Master Degree (MSc), followed by a Bachelor's Degree. He has extended his valuable service in Faculty of Letters, Diponegoro University and has been a recipient of many award and grants. Currently, he is working as a faculty. His international experience includes various programs, contributions and participation in different countries for diverse fields of study. His research interests reflect Land use, plywood factory, agriculture, brackishwater pond.

\section{EDWARD E. PANDELAKI}

He is a lecturer at Department of Architecture Engineering Faculty Diponegoro University. He graduated from University of Diponegoro with bachelor and master degree in architecture, and completed his $\mathrm{PhD}$ at Kobe University Japan. His research interest in sustainable housing and settlement.

\section{DJOKO INDROSAPTONO}

$\mathrm{He}$ is a lecturer at Department of Architecture Engineering Faculty Diponegoro University. He graduated from University of Diponegoro with bachelor as well as his $\mathrm{PhD}$. His research interest in behavioural architecture, urban infrastructure, urban heritage management. 